\title{
Coronavirus Disease (COVID-19), Chemical Structure, Therapeutics, Drugs and Vaccines
}

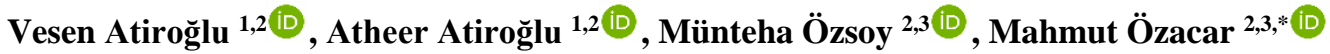 \\ 1 Sakarya University, Biomedical, Magnetic and Semiconductor Materials Application and Research Center (BIMAS-RC), \\ 54187, Sakarya, Turkey \\ 2 Sakarya University, Biomaterials, Energy, Photocatalysis, Enzyme Technology, Nano \& Advanced Materials, Additive \\ Manufacturing, Environmental Applications, and Sustainability Research \& Development Group (BIOENAMS R\&D \\ Group), 54187 Sakarya, Turkey \\ 3 Sakarya University, Science \& Arts Faculty, Department of Chemistry, 54187, Sakarya, Turkey \\ * Correspondence: mozacar@hotmail.com (M.O.);
}

Scopus Author ID 6603796256

Received: 27.02.2021; Revised: 3.04.2021; Accepted: 6.04.2021; Published: 20.04.2021

\begin{abstract}
Biochemistry has the main role to play in understanding the structure of viral to develop techniques and materials used by clinicians, virologists, and researchers, as well as isolation of therapies and vaccines. Biochemistry helps to understand the molecules that manage virus structure and function can accelerate discovering means to treat and avoid infectious disease. The significant contributions of biochemistry are providing to understanding and monitoring the spread of coronaviruses. COVID-19 is a novel type of coronavirus influence humans and was recognized in 2019. The terms severe acute respiratory syndrome coronavirus 2 (SARS-CoV2), 2019 novel coronavirus, and COVID-19 mention the same virus. All present medication choices are based on experience with MERS, SARS, and other new influenza viruses. Thus, it is essential to understand the virus structure and its clinical features to respond to the COVID-19 outbreak. Intensive studies are currently being carried out to develop specific drugs or vaccines for the COVID-19 coronavirus. This study will shed light on the various present and future research efforts to treat the COVID-19 by evaluating past studies to assist the therapeutics for COVID-19 improve quickly.
\end{abstract}

Keywords: Coronavirus 2019-nCoV; diagnosis; COVID-19; viruses; infectious diseases.

(c) 2021 by the authors. This article is an open-access article distributed under the terms and conditions of the Creative Commons Attribution (CC BY) license (https://creativecommons.org/licenses/by/4.0/).

\section{Introduction}

The COVID-19 is the name given to the 2019 novel coronavirus, and it is a novel strain of coronavirus [1,2]. Formerly, six coronaviruses (CoVs) are recognized to cause diseases in humans, and these can be defined as low, highly pathogenic CoVs [3,4]. According to the World Health Organization (WHO), the WHO China Office reported pneumonia of unknown etiology in Wuhan City at the end of 2019 [5,6]. The Chinese authority of the health [7] showed that the patients primarily tested negatively for the viruses and respiratory bacteria but later tested positive for a new coronavirus [8-10]. The virus was presently isolated and its genome sequenced by Chinese scientists [11]. In February 2020, the coronavirus disease 2019 was selected as the disease COVID-19 by WHO [12]. The COVID-19 can cause infections in different animals and most infections of the respiratory tract in individuals, including the Middle East respiratory syndrome (MERS) and severe acute respiratory syndrome (SARS) [13,14]. 
The COVID-19 virus is completely different from the viruses accountable for SARS and MERS [15,16]. The COVID-19 genome sequences got from the patients part a $79.5 \%$ sequence related to that of SARS-CoV $[17,18]$. The signs and symptoms characteristically occur among two weeks after contact and consist of fever, coughing, respiratory disorders, pain in the chest, and trouble breathing [2,19]. Possibly deadly complications include pneumonia and kidney failure [20,21].

As on December 30, 2020, a total number of 82,739,879 cases of COVID-19 (with $1,804,879$ deaths) have been reported from 191 countries worldwide according to the WHO situation report. United States of America as epicenter of the current COVID-19 reported maximum deaths associated with COVID-19 (20,034,309 laboratory confirmed cases with 347,713 deaths). The countries where more than 2,000,000 people are affected include India(10,264,426), Brazil (7,577,890), Russia(3,131,550), France (2,600,498), England $(2,432,888)$, Turkey $(2,194,272)$ and Italy $(2,083,689)[12]$.

In the present development, the United States of America and most European nations bear the brunt of the burden of illness and death associated with COVID-19 relative to other nations [12]. The latest increase in consistently reported patients with COVID-19 has now reached acute care stocks, restricting acute care coverage to just a limited percentage of critical patients. This may also have led to the elevated fatality ratio found during the COVID-19 outbreak.

\section{Chemical structure of COVID-19}

Coronaviruses encode four main structural proteins, namely Envelope (E), Membrane $(\mathrm{M})$, Nucleocapsid $(\mathrm{N})$, and Spike (S), which are defined in feature as below.

\subsection{Nucleocapsid $(N)[N$ protein].}

There are multipurpose of the $\mathrm{N}$ protein of coronavirus. It supports the formation of the complex with the genome of viral, enables the interaction of $\mathrm{M}$ protein through virion assemblage, in addition to increases transcription efficiency of the virus [22,23]. There are three extremely distinct and conserved domains, namely a linker region (LKR), an N-terminal domain (NTD), and a C-terminal domain (CTD) [24]. The charged LKR is rich with arginine and serine and is also recognized as SR (Serine and Arginine) domain [25]. The LKR region is responsible for the cell's signaling and is also able to interact with in vitro RNA directly [26]. The NTD binds with the 3' end of the viral genome, probably by its highly splay in the sequence and length and electrostatic interactions [26]. Compared to SARS-CoV, the N protein of COVID-19 has five amino acid mutations, wherever the two mutations are in the intestinally distributed region, one in the 103, 217, and 334 positions of NTD, LKR, and CTD, respectively [27].

\subsection{Envelope (E)[E protein].}

The role of protein $\mathrm{E}$ in pathogenesis and virus release is multifunctional. It is the most mysterious and lowest among the main structural proteins [27,28]. It is a small integral polypeptide membrane that functions as an ion-channel. The E protein contains three domains: an excellent $\mathrm{C}$ terminal domain, a large hydrophobic transmembrane domain, and a short hydrophilic amino-terminal domain. The E protein of COVID-19 exposes a similar amino acid composition without any change [27]. 


\subsection{Membrane (M) [M protein].}

The Membrane (M) (M protein) is highly varied concerning amino acid contents. It is the most bountiful viral protein present in the virion structure, giving the viral envelope a distinct form. It binds to nucleocapsid and acts as the central organizer of coronavirus assembly [29]. The M protein has three transmembrane domains, flanked by a long carboxy-terminal inside the virion short amino-terminal outside the virion [30]. Generally, the viral framework is conserved by M-M interaction. In the study made by Wu et al., the M protein of COVID-19 does not have any amino acid substitution compared to the SARS-CoV [27].

\subsection{Spike (S) [S protein].}

The coronavirus spike $(\mathrm{S})$ or [S protein] is a multifunctional class I transmembrane protein. This rests on the top of the virion like a trimmer, giving the virion a 'corona' or crownlike outer look. Operationally, interaction with cellular receptors of various kinds is necessary for the entry of infectious virion components within the cell [31]. Moreover, it works as a significant feature for tissue tropism [30]. Particularly, S protein is a single vital immune dominant protein of coronaviruses that prompt the host immune response. The $S$ protein of all coronaviruses is divided into two domains [32]. Initially, S1, facilitates the binding of host receptors while the other, S2, is responsible for the fusion. Already, the structural study of COVID-19's S-proteins exposed 27 amino acid substitutions over a period of 1273 amino acid stretches [27,29]. Inter the six substitutions, placed in the receptor-binding domain (RBD) (aa 357-528) while four substitutions in the receptor-binding motif (RBM) at the CTD of the S1 domain. There is no shift in amino acid in the RBM that binds directly to the angiotensinconverting enzyme-2 (ACE2) receptor in SARS-CoV [33]. It is currently important to identify how many changes will be essential to alter the host's tropism. The evaluation of sequence exposed 17 non-synonymous variations in the primary sequence of SARS261 CoV-2 than the later isolates of SARS-CoV, as shown in Figure 1(A-C). The modifications were located distributed in the open reading frame (ORF) 1ab, ORF8 (4 substitutions), spike gene (3 substitutions), and ORF7a (single substitution) over the genome of a virus with 9 substitutions [34]. Particularly, the same non-synonymous modifications were detected in a familial group showing that the viral evolvement might have happened throughout person-to-person transportation $[35,36]$. Such adaptive evolvement is public and constitutes a constantly ongoing process once the spread of virus between new hosts [31,37]. Despite this fact, no changes in the functional occur in the virus associated with this adaptive development. Observing the viral mutations that happen throughout subsequent human-to-human transmission is verified [38,39]. Fusion Animation has shaped a 3D model of the COVID-19 surface as a new model for use in drug development. The model was created by assembling 3D parts related to structures of COVID-19 coronavirus accessible in open databases. The previous study presented that the $\mathrm{M}$ protein exposed is complexed with human leukocyte antigen serotype. The protein distribution on the virus surface was aligned by a random process [28]. The general picture surface protein density has been summary to assistance show $\mathrm{M}, \mathrm{E}$, and S proteins. A particle system created the M lipid itself to yield a random and organic result, Figure 1D [40]. 


\section{Physicochemical Features.}

The virus particle diameter has around $60 \sim 100 \mathrm{~nm}$ with a round or oval shape [42]. The COVID-19 can be inactivated by heating at $56^{\circ} \mathrm{C} 30 \mathrm{~min}$ or by using UV, and sensible to many disinfectants like ethanol (75\%), acetic acid, diethyl ether, and chlorine. It has been described that COVID-19 was more stable on stainless steel and plastic than copper [43].

A
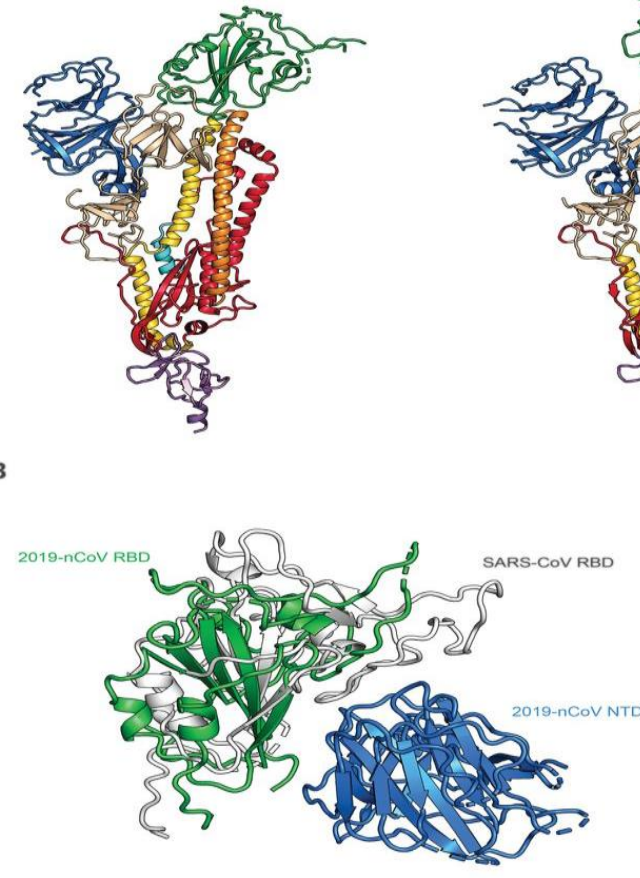

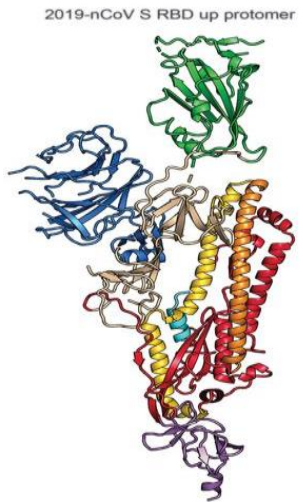

C

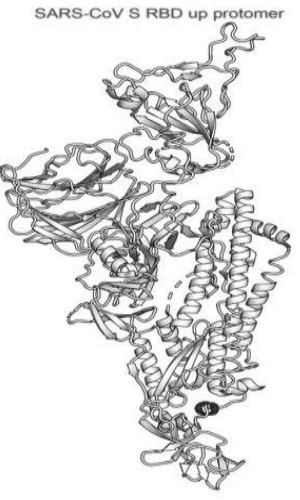

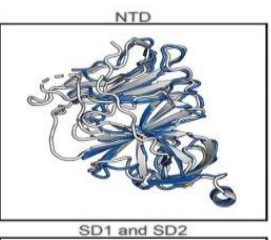


Figure 1. Structural comparison between COVID-19 (2019-nCoV S) and SARS-CoV S. (A) Single protomer of COVID-19 with the RBD in the down conformation. COVID-19 protomer in the RBD is exposed (center) following to a protomer of SARS-CoV S in the RBD up (right), shown as stripes and colored white.;(B) RBDs of COVID-19 and SARS-CoV aligned based on the position of the neighboring NTD from the neighboring protomer; (C) Structural domains from COVID-19 S have been aligned to their complements from SARS-CoV S [41]; (D) A representation of three-D of the COVID-19 surface [40].

\section{Cell Entry and Receptor Connections}

The angiotensin-converting enzyme 2 (ACE2) in humans is a receptor appropriated by COVID-19 for cell access, like SARS-CoV[32]. ACE2 is a type I membrane protein in the heart, lung, intestine, and kidney generally connected by heart illnesses. ACE2 contains an N- 
terminal peptidase domain and a $\mathrm{C}$ terminal Collectrin-like domain that ends with a single transmembrane helix and an around 40-residue intracellular fragment [43]. Furthermore, the ACE2 can bind directly with the $\mathrm{S}$ proteins of CoVs to split angiotensin (Ang) I to generate Ang-(1-9) [44].

The CoVs S protein is a metastable prefusion validation that undergoes a remarkable structural reorganization to fuse the viral membrane with the host cell membrane [45]. Reasonable to find out COVID-19's capacity for infecting humans, the RBD of its S-protein, which interacts with ACE2, has been examined. The structural and biophysical evidence confirmed that COVID-19 S-protein is likely to bind more than 10-20 fold higher affinity to human ACE2 than SARS-CoV [41]. Another structural suggestion proposes that the ACE2B0AT1 complex can bind two S-proteins concurrently [46,47].

The COVID-19 is an envelope with positive-sense, single-stranded RNA beta coronavirus [48,49]. The genome of the CoVs, ranging in length from 26-32 kilobase, is possibly the major viral RNA identified [50]. Similar to SARS and MERS, the genome of COVID-19 encodes structural proteins (for example, spike glycoprotein), non-structural proteins (for instance, 3-chymotrypsin-alike protease, helicase, and papain-alike protease), and accessory proteins. Functionally important ORF1a and ORF1b, On the other hand, the interrelationships of functionally important ORF1a and ORF1b and other principal structural proteins such as E, M, N and S proteins are also extremely good and are clearly shown in Fig. 2. While the $\mathrm{E}$ and $\mathrm{M}$ proteins are necessary for the assembly of the virus into host cells, it has been stated in the literature that the affinity of the $S$ protein is very important for binding to the host cells, as the RBD of the S protein provides binding with ACE2 [51].

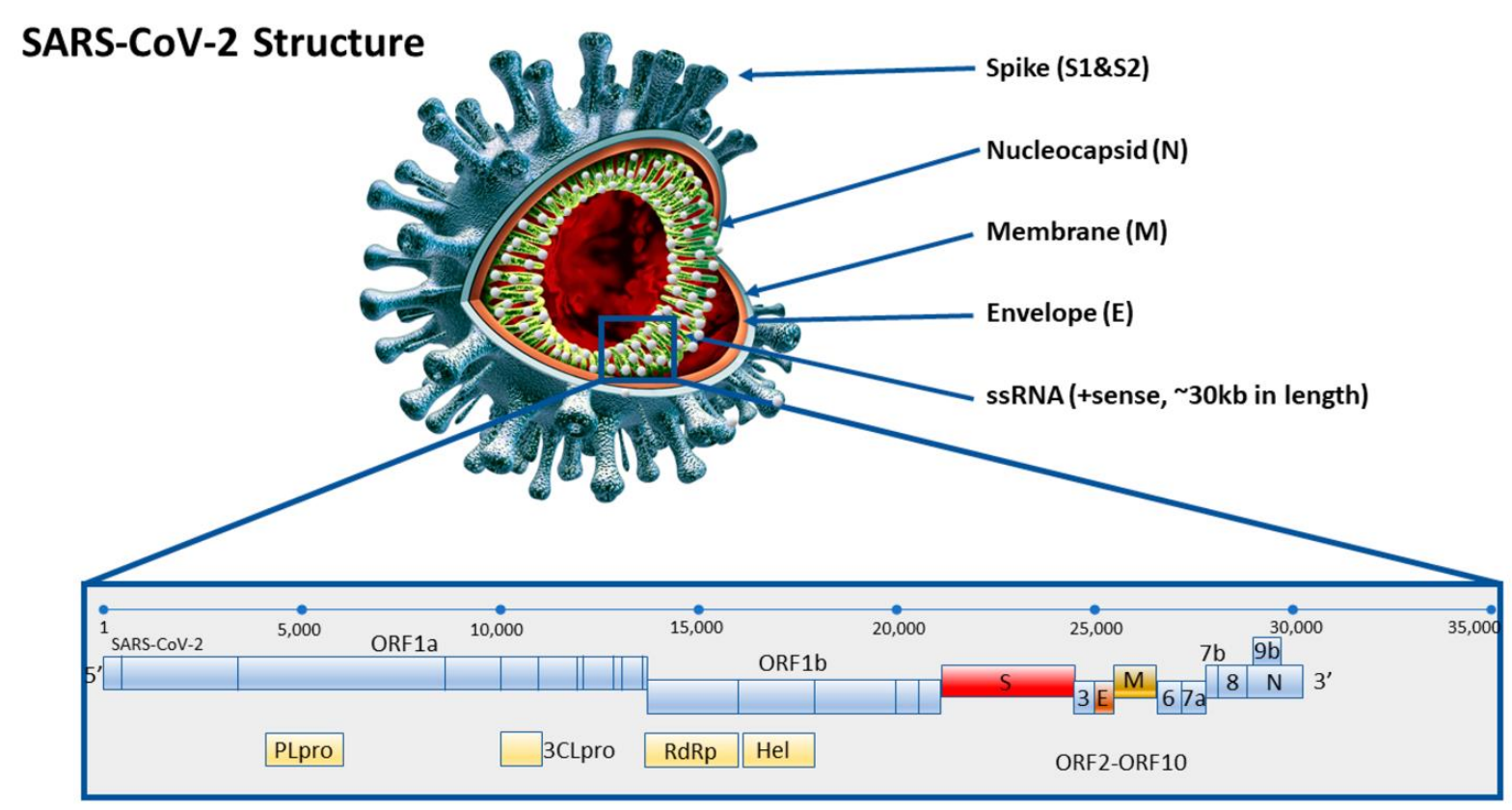

Figure 2. Organization of COVID-19 genome [51].

Liu et al. showed that the COVID-19 spike RBD is notably dissimilar from the SARSCoV spike RBD, mainly in the regions which bind to the ACE2 (Figure 3). This modification efficiently removes the use of formerly therapeutic peptides and industrialized antibodies for the SARS-CoV. A probable rapid remedy to suppress the RBD-ACE2 interaction to stop the infection is to produce peptides reproduced from RBD and ACE2 and concoctions thereof [52]. 


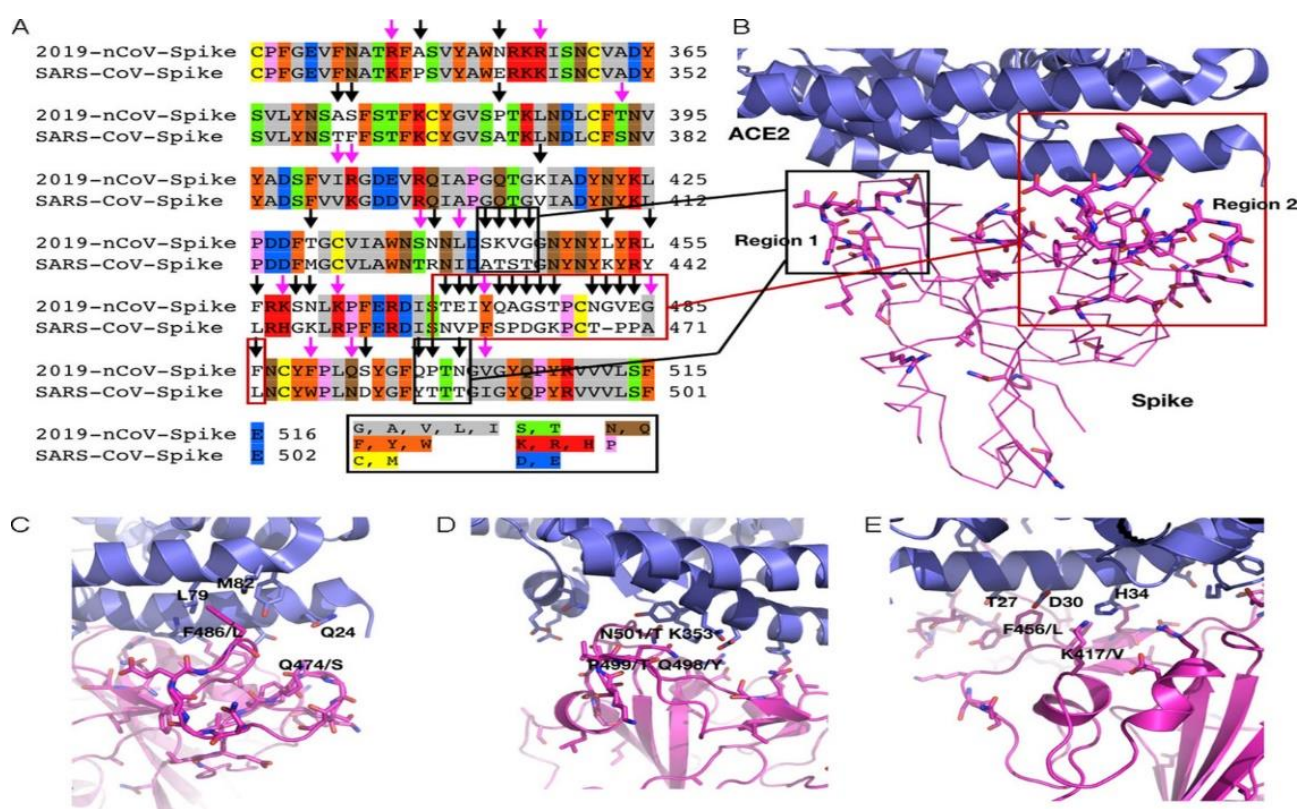

Figure 3. (A) Amino acids sequence position in the COVID-19 and SARS-CoV spike domains. Preserved (pink arrows) and nonconserved (black arrows) mutations are highlighted. (B)Numerous binding connections between the COVID-19 spike protein (pink) and ACE2 (blue; spike protein homology).(C-E) Zoomed in views of some spike protein-ACE2 interactions described in (B) [52].

In type 2 alveolar epithelial cells surface of lungs, the ACE2 is displayed within the renin-angiotensin system (RAS) [53,54]. The ACE2 is a significant regulating factor of the RAS and shares around 60\% homology with ACE [55]. The ACE2 converts (Ang) II into Ang(1-7), which actions on the Mas receptor, expressed on a cell lineage in numerous tissues pertinent to cardiovascular illness to discreetly lower blood pressure over vasodilation and by secretion of water and sodium from kidney, moreover produce nitric oxide to reduce inflammation [56,57].

There are two theories to clarify the conflicting hypothetical pathways by which the inhibition of RAS with an angiotensin-converting enzyme inhibitor (ACEi) or angiotensinreceptor blocker (ARB) can be injurious or protective in COVID-19 [58,59]. The first one supposes that severe acute respiratory COVID-19 improves its entry into the cell by binding to ACE2. The addition of an ACEi or ARB could increase the abundance of the ACE2 and increase the viral entry. The second hypothesis assumes that (Ang II) causes the lung's injury by activating the type 1 angiotensin receptor (AT1R), initiating the infection and fibrosis. The decrease in the production of Ang II with an ACEi or obstructive action of Ang II-AT1R with an ARB improves the formation of Ang-(1-7) by ACE2 and of the Mas receptor activity, which leads to a decrease the lung inflammatory and fibrosis and consequently reduces injury of the lung $[53,60]$.

\section{COVID Diagnosis}

For COVID-19, virus-specific antibodies can be monitored from the serum/plasma sample. IgM antibody begins to become positive on days 3-4 of the symptoms or days 7-10 of infection and IgG antibody on days 11-14 of the infection. Seroconversion has been shown to occur in $50 \%$ of patients on days 7 and 14 in all patients. 


\section{COVID-19 Treatment}

In general, there are different approaches used together in CoVID-19 treatment, and in these approaches, drug compounds can be selected according to virus-based and host-based treatment $[61,62]$. The first process offers broad-spectrum antiviral drugs, previously used to treat viral infections by typical assays. These drugs' effects on pseudo coronaviruses, cytopathic, viral production, and living cells plaque formation can be measured in these approaches. This method contains interferon I and interferon II $[63,64]$. These drugs have pharmacodynamic and pharmacokinetic features with their drug regimens and side effects $[20,65]$. On the other hand, the anti-COVID-19 virus has no specific effects and can be related to extreme opposite reactions. The second process includes improving exact novel drugs created on the biophysical and genome understanding of the COVID-19 virus patients. The method includes an inhibitor of the host cell endocytosis virus, inhibitors targeting specific viral enzymes found in a viral replication cycle, inhibitors of the host cell's protease enzyme, targeting human-derived or humanized monoclonal antibodies (mAb) S1 RBD, and antiviral targeting peptide S2. On the other hand, the improvement of these drugs may permit drugs to become beneficial treatment choices, but it will take a long time to supply dependable drugs for COVID-19 virus patients $[66,67]$. The chief problem of this method is that though most of the recognized drugs display in vitro anti-coronavirus activity, the greatest of them are not beneficial in clinical treatment because they have half the EC50 value of the anti-coronavirus, which is considerably higher than the concentration of peak serum that can be performed at the treatment dose or associated with immunosuppression $[11,68]$. The third process includes the publication of a chemical library with various compounds or databases containing knowledge about the properties of transcription for different cell lines [69]. This process may provide fast and high yields for many simply obtainable compounds and then estimate them with an antiviral test. Several drugs with significant immunological and physiological effects such as kinase signal transduction, an estrogen receptor, DNA synthesis or repair, lipid, and protein metabolism have been recognized in these drug reuse programs [70,71]. The fourth process also includes treatment methods used by Acupuncturists with a meaningful result in the management of patients with COVID-19. One hypothetically effective method is a synthetic form of quinine, called hydroxyl chloroquine [72-74]. Presently, malaria is treated with natural and synthetic forms of the Chinese herbal medicine Qing Hao. On the other side, Cortegiani et al. found that chloroquine appears to be effective in reduced the replication of COVID-19 in vitro [74]. Furthermore, Gao et al. showed that chloroquine is significantly effective compared to a control group in 100 patients for symptoms duration, decreasing pneumonia exacerbations, and viral clearance postpone. Also, this study displayed that chloroquine might decrease the length of hospital stays [75]. Chloroquine and oxygen treatment is recommended by the Infectious and Tropical Disease Society and the Dutch Centre for Disease Control in Italy, with separate dosage guidelines compared with the Chinese Protocol. Colson et al. conclude that sufficient preclinical indication is available for the chloroquine used in COVID-19 treatment [76].

In 2003, Chinese medicine had been used in the same disorders during the SARS outbreak, with recognized clinical successes [77]. Despite primary clinical achievements and hopeful research, the treatment rate for COVID-19 remains difficult to succeed. The herbal formula Qing Fei Pai Du Tang had a reply rate of 90 percent of a total of 214 clinical cases of COVID-19 related pneumonia, with respect to the National Administration of Traditional 
Chinese Medicine [77,78]. Patients were treated in the provinces of Shanxi, Hebei, Shanxi, and Heilongjiang during this clinical research. A description of the response rate of $90 \%$ is as follows: symptoms changed dramatically in around $60 \%$ and the remaining $30 \%$ stable [79]. Another research surveyed 701 COVID-19 patients in ten Chinese cities who received Qing Fei Pai Du Tang medication. A total of 130 patients (18.5\%) were cured, symptom changes were achieved in a further 268 patients (38.2\%), and recovery occurred in 212 patients $(30.2 \%)$. Other studies showed that Lian Hua Qing Wen Capsule decreased the COVID-19 symptoms and upgraded healing [80-82]. Besides, the Lianhuaqingwen Capsules and Shu Feng JieDu Capsules have played a significant role in treating infectious diseases like influenza A (H1N1) [83]. Conversely, the safety and effectiveness of these drugs in COVID-19 require to be more validated vi clinical tests.

Furthermore, nucleoside analogs may have numerous action mechanisms, including chain termination, lethal mutagenesis, and nucleotides' biosynthesis inhibition [84-86]. The tribavirin and favilavir are nucleoside analogs representatives, which pooled with Avigan and oseltamivir in acute influenza care are superior to oseltamivir only [87]. On the other hand, the Neuraminidase inhibitors such as zanamivir and oseltamivir are suggested as antiviral treatment in infection [88]. The oseltamivir has been commonly used for COVID-19 in China. The chiefly point for patients is the beginning of antiviral medication immediately after disease initiation. It has revealed that neuraminidase inhibitors are more active in MERS-CoV infection, but there is no significant indication that oseltamivir is influential in COVID-19 care.

Moreover, Remdesivir may be the possible drug for the care of COVID-19. The experiments in animals exhibited that effectively decrease the virus titer of mice infected with COVID-19 comparing to healthy mice, decrease the damage of the lung tissue [89]. Conversely, the safety and efficiency of Remdesivir in patients with COVID-19 still need more clinical research. Presently, other types of drugs have been starting to be influential in vitro, like fusion peptides, RNA synthesis inhibitors, and anti-inflammatory drugs [90].

In Turkey, in the first Covid-19 cases encountered, it was taken into account the accumulation of experiences and treatment protocols of China, previously living the process of combating the pandemic. But after the first 1-2 weeks, Turkey has developed its treatment algorithm based on its own clinical observation and experience. Furthermore, the Ministry of Health also made updates to the algorithm according to the developments within the framework of the recommendations of the Scientific Board established after the Coronavirus outbreak. In Turkey, a dissociated and effective treatment protocol was formed differently from other applications in the world. The strategies developed in the light of the objective recommendations of the Scientific Committee based on scientific data, the professional experience of healthcare professionals who implement these strategies, their organizational capabilities, well-equipped and extensive hospital infrastructure and the capacity of intensive care units with high-quality equipment above the world average was formed a great advantage in combating Covid-19 [68].

- Since the Ministry of Health has sufficient drug stocks, hydroxychloroquine treatment was started at the early stage of the disease.

- Favipiravir treatment was started when replicating the virus, that is, before the disease gets seriously worse, before the need for intensive care. Whereas in the first applications, it was started in the intensive care process, this is an application that has been put into practice in the intensive care stage of the disease in many countries still, but it is thought that it is not very effective at this stage. 
- It was given up from early intubation (invasive ventilation) in intensive care patients. Because it was observed that this did not change the course of the disease much. Noninvasive ventilation technique (continuous positive pressure airway (CPCA)) has begun to be used instead of invasive ventilation, which is insufficient. Thus, the risks of lung damages caused by invasive ventilation were also prevented.

- It was also observed that the disease was not a typical ARDS table as described, additional problems such as coagulopathy (coagulation disorder) also occurred, and patients were also lost due to this reason. Accordingly, anticoagulant drugs have also affixed the algorithm.

- For the diagnosis of Covid-19, the capacity of quantity and quality of IT, present in hospitals in Turkey, more effective than PCR, has increased its capability for rapid diagnosis.

In the cure of Covid-19 patients in Turkey, the following protocols were applied after grouping patients. Mild, possible/definitive Covid-19 outpatient case treatment; hydroxychloroquine and oseltamivir therapy was recommended for 5 days period for patients with mild symptoms, under 50 years of age, pneumonia and concomitant hypertension, cardiovascular diseases, chronic airway disease, diabetes, cancer, immune suppression and patients with undiagnosed/influenza [91]. Moderate, possible/definitive Covid-19 service treatment; it was recommended to azithromycin addition for 5 days to hydroxychloroquine and oseltamivir therapy for the cure of patients [75,92], who need hospitalization, but do not have a pneumonia picture and clinic heavy and do not have accompanying comorbid diseases, and the cases in the middle clinic [91,93]. Serious, possible/definitive Covid-19 case treatment; it was recommended to use favipiravir for 5 days, which is an effective antiviral in the management of patients with acute pneumonia, concomitant comorbid diseases, and severe clinic, and to add favipiravir to the treatment of patients who worsen the clinic while taking hydroxychloroquine treatment in cases of mild disease, and develop pneumonia. The following suggestions can be made for treatments in some special cases by the experience gained during the treatments in Turkey. According to clinical, laboratory, and radiological findings, among those who started Covid-19 treatment, it is known that it is appropriate to add drugs such as quinolone to the effective atypical agents' beta-lactam antibiotics to those who are considered to have infection/pneumonia $[33,91]$.

Inhaler drugs that should be given with nebulizer should be administered with a metered-dose inhaler due to the risk of transmission. In non-invasive mechanical ventilation (NIMV) applications, the mask should be preferred for reducing infectious. It is recommended to evaluate the option of follow-up without treatment if the symptoms/clinic are mild, if comorbid conditions are not accompanied in pregnant women with Covid-19 definitive diagnosis, to use treatment Lopinavir $200 \mathrm{mg} /$ ritonavir $50 \mathrm{mg}$ tb 2x2 10/14 days orally and to add hydroxychloracine 5 days depending on the situation. Favipiravir should not be used in nursing mothers and pregnant women [91].

There is concern about the use of nonsteroidal anti-inflammatory drugs (NSAIDs) [19]. This concern has evolved because several young patients used NSAIDs in the early phase of the disease, and their condition deteriorated. However, currently, there is insufficient data to support NSAID use or to ban it altogether. For suspicious cases, acetaminophen should be preferred as an analgesic and antipyretic. In all Covid-19 patients who are hospitalized for the prevention of venous thromboembolism, prophylaxis is recommended using low molecular weight heparin if there are no contraindicated conditions such as active bleeding and severe 
thrombocytopenia. In intensive care patients whose clinic worsens while lying in the service, the addition of steroid 1-2 mg/kg/day 5-7/day and high dose of vitamin C, $25 \mathrm{~g} / \mathrm{day}$, according to the clinical condition of the patients, the addition of IL-6 inhibitor tocilizumab in patients with cytokine storm findings, should be evaluated [91].

Immune plasma therapy and stem cell therapy have been begun to use as promising treatments in patients whose general condition has deteriorated and did not respond to treatment [94,95].

Since SARS-CoV-2 is a newly encountered virus, no vaccine, monoclonal antibody, or a drug that directly affects it has been developed yet. Although there are promising studies on vaccine and drug development, there is a high probability of not being completed for this pandemic period. Therefore, one of the fastest and easiest treatment options that first comes to mind and can directly target SARS-CoV-2 is to take serum or plasma from people who have survived this disease and are considered to contain antibodies against this virus and use it for both preventive and therapeutic purposes. Serum or plasma treatment has started to be easier and find application area by increasing the number of those who survived the disease. Unlike the vaccine, this use falls into the class of passive antibody therapy (PAT) and includes benefits and risks $[68,91]$.

Considering the previous experience with plasma treatment, it seems to be the only available treatment option for the Covid-19 pandemic in today's conditions where vaccines and drugs could not be developed. One of the most important factors in the positive outcome of this treatment can be summarized as the presence of sufficient neutralizing antibodies in the transplanted plasma, and another is the rapid start of treatment of individuals with potential risk factors such as age. Briefly, since the recovered patients' immune systems reacted differently to the virus, treatment should be directed considering the possibility of not having enough antibodies or not at all, if very few $[1,96]$. In the treatment to be performed 1 week after the first plasma treatment, it is more appropriate to give the plasma of another donor or the plasma from a few donors to the patient. This is valid for the current situation, but it is expected that an efficacy test will be carried out before it is given for neutralization in the future. The PAT carries several risks. There can also be an enhanced risk of antibody-dependent viral infections, and its molecular mechanism is unknown. Besides, there is another risk that antibody therapy will suppress the development of acquired immunity. While this situation requires that the antibody level in the treatment of PAT is sufficient until the disease is completely eliminated, it should be considered that an immune memory cannot be formed due to the metabolism of the externally given antibodies [91,97].

Consequently, the vaccine should be taken into account after PAT. In addition, the duration of the plasma antibody and the duration of effectiveness of this acquired immunity are also important as additional information [98]. In this pandemic era, it is expected to pay attention to the vaccination of individuals who are not yet immune, rather than vaccinating individuals who have naturally active antibody counts [91,99].

It is not known how it will affect the people who got and survive this disease in the long term [98]. The 'COVID-19 Patient Monitoring Center' was opened by the Istanbul Medical Faculty to answer these questions. This center will investigate whether the coronavirus causes permanent damage in patients by performing various tests and examinations on those who got coronavirus and survive [100]. While struggling with this disease, some problems were observed in organs such as the lungs, heart, intestines, and liver. Some publications were started to be discussed in the literature; some question marks whether these problems will continue, 
especially whether lung, liver, or kidney problems will be carried in the long term $[94,101]$. Thereupon, 'COVID-19 Patient Monitoring Center' was established in Turkey, and this center is the first center in Turkey and the world for this goal. For patients who have had severe COVID-19 infection, some problems that may occur by following them at 1, 3, 6, 9, and 12th months after their treatment will be diagnosed and treated at this center [102].

\section{Vaccine Development for COVID Treatment}

Although there is no whole and complete treatment for COVID-19 yet, two treatment strategies have gained priority: the first is to rearrange and use previously approved pharmacological agents, and the second is to develop new treatment strategies to reduce the ever-spreading virus-related morbidity and mortality. The second strategy is to prevent further spread and relapse in society. For this purpose, the advancement, controlling production, and delivery of an effective and secure vaccine with scientists' contributions as a long-term solution proposal will reach everyone as soon as possible [103].

\subsection{Non-replicating viral vectors (NRVV).}

Adenoviral-based candidates are widely used for non-recurrent SARS-CoV-2 vaccines. Adenoviruses are characteristic double-stranded DNA viruses that inactivate replication by deletion of the E1 regions. Upon infection of target cells, there is an up-level transgene expression and upregulation of costimulatory molecules that chemokine responses and elicit cytokine, enhancing immunogenicity. SARS-CoV-2 is thought to use the S-protein to enter cells, so all vaccines in current trials contain either the S-protein subunits or the full-length $S$ protein [103].

\subsection{Messenger RNA vaccine candidates.}

Hitherto, there is no FDA-approved mRNA vaccine for humans, but considering the extra conditions brought by the COVID-19 global epidemic, mRNA vaccine studies are being tried as a new method. Since the production of nucleic acid vaccine candidates is faster and cheaper than protein subunit vaccines, a few mRNA-based SARS CoV-2 vaccine candidates have been developed and are recently being tested. Traditional mRNA vaccine design generally includes an open reading frame of the targeted antigen (spike protein for SARS CoV-2) with a $3^{\prime}$ polyadenylated tail that generates both humoral and cellular immune responses. The degradation tendency of mRNA has been a major barrier to mRNA vaccine development; Therefore, stability and proper intracellular mRNA translation are of paramount importance for achieving these vaccine candidates. Miscellaneous methods have been advanced to overcome these issues, such as extracting double-stranded RNA and buried mRNA in lipid nanoparticles [103].

\subsection{Self-amplifying messenger RNA vaccine candidates.}

With the latest technological approaches, self-amplifying RNA (saRNA) vaccines have been advanced in extension to non-amplifying mRNA vaccines. Trinidad ass, these vaccines are highly promising as they have the potential to induce a stronger immunological response than a non-replicating mRNA vaccine, although this is a significant downside given their RNA sequence content for the protein [103]. 


\subsection{DNA vaccine candidates.}

DNA-based vaccine candidate has many superior properties, such as the DNA molecule's stability compared to RNA, and the ability of DNA structures to generate a large number of mRNA molecules, thereby increasing the immunological exposure of a DNA-based vaccine target antigen. In addition to all these advantages, DNA-based vaccines have less cooling requirement than their mRNA-based response due to the thermal stability of DNA [103].

\subsection{Inactivated whole-virus vaccine candidates.}

Although the vast majority of successful vaccines in the historical period are vaccines that induce immunity using inactivated pathogens, the prolonged production of such vaccines has reduced the possibility of using inactivated full virus vaccine candidates in the COVID-19 pandemic. In proportion to other genres of vaccines, inactivated viral vaccines have fewer side effects, and most of the systemic side effects are mild, including localized rash and pain at the injection site [103].

\subsection{Protein subunit vaccine candidates.}

The synthetic protein subunit approach is an alternative vaccine generation method between nucleic acid-based mechanisms and inactivated complete virus vaccines, which part of SARS-CoV-2 vaccine candidates includes a recombinant spike protein expressed in various cell lines. Similar to RNA-based approaches in protein subunit vaccines, peptides are often unstable in vivo and are typically packaged in nanoparticles adsorbed onto specific adjuvants structured to increase the protein cargo's uptake into host antigen-presenting cells [103]. Vaccines attempted to be developed for SARS-CoV-2 are summarized in Table 1.

Table 1. Short-form list of SARS-CoV-2 vaccines in human clinical trials of Phase $\geq 2$.

\begin{tabular}{|c|c|c|c|c|c|}
\hline GENRE & ESTABLISHMENT & $\begin{array}{l}\text { CLINIC } \\
\text { PHASE }\end{array}$ & $\begin{array}{l}\text { PROPER } \\
\text { NAME }\end{array}$ & $\begin{array}{l}\text { REGISTRY } \\
\text { INDEX }\end{array}$ & REFERENCES \\
\hline \multirow{7}{*}{$\begin{array}{l}\text { INACTIVATED } \\
\text { VACCINES }\end{array}$} & $\begin{array}{l}\text { Institute of Medical Biology, } \\
\text { Chinese Academy of Medical } \\
\text { Sciences }\end{array}$ & $1 / 2$ & $\begin{array}{l}\text { Inactivated SARS- } \\
\text { CoV-2 Vaccine }\end{array}$ & NCT04470609 & {$[103,104]$} \\
\hline & $\begin{array}{l}\text { Research Institute for } \\
\text { Biological Safety Problems, } \\
\text { Republic of Kazahstan }\end{array}$ & $1 / 2$ & QazCovid-in ${ }^{\circledR}$ & NCT04530357 & {$[103]$} \\
\hline & $\begin{array}{l}\text { Bharat Biotech (Whole } \\
\text { Virion Inactivated) }\end{array}$ & $1 / 2$ & $\mathrm{BBV} 152 \mathrm{~A} / \mathrm{B}$ & NCT04471519 & [103] \\
\hline & $\begin{array}{l}\text { Beijing Institute of } \\
\text { Biological } \\
\text { Products/Sinopharm }\end{array}$ & $1 / 2$ & Inactivated & ChiCTR2000032459 & {$[104]$} \\
\hline & $\begin{array}{l}\text { Bejing Institute of Biological } \\
\text { Products/Sinopharm }\end{array}$ & 3 & BBIBP-CorV & $\begin{array}{l}\text { NCT04560881 } \\
\text { ChiCTR2000034780 }\end{array}$ & {$[103,106]$} \\
\hline & $\begin{array}{l}\text { Wuhan Institute of Biological } \\
\text { Products/Sinopharm }\end{array}$ & 3 & $\begin{array}{l}\text { Inactivated COVID- } \\
19 \text { vaccine (Vero } \\
\text { cells) }\end{array}$ & ChiCTR2000034780 & {$[103,106,107]$} \\
\hline & Sinovac & 3 & CoronaVac/PiCoVacc & NCT04456595NCT0458234 & {$[103,106,107]$} \\
\hline $\begin{array}{l}\text { NON- } \\
\text { REPLICATING }\end{array}$ & $\begin{array}{l}\text { CanSino Biological } \\
\text { Inc./Beijing Institute of } \\
\text { Biotechnology }\end{array}$ & 2 & $\begin{array}{l}\text { Adenovirus Type } 5 \\
\text { Vector }\end{array}$ & ChiCTR2000031781 & [104] \\
\hline
\end{tabular}




\begin{tabular}{|c|c|c|c|c|c|}
\hline GENRE & ESTABLISHMENT & $\begin{array}{l}\text { CLINIC } \\
\text { PHASE }\end{array}$ & $\begin{array}{l}\text { PROPER } \\
\text { NAME }\end{array}$ & $\begin{array}{l}\text { REGISTRY } \\
\text { INDEX }\end{array}$ & REFERENCES \\
\hline \multirow[t]{11}{*}{$\begin{array}{l}\text { VIRAL } \\
\text { VECTORS }\end{array}$} & $\begin{array}{l}\text { Cansino Biological } \\
\text { Inc./Bejing Institute of } \\
\text { Biotechnology }\end{array}$ & 3 & Ad5-nCoV & NCT04526990NCT04540419 & {$[103,106,107]$} \\
\hline & $\begin{array}{l}\text { University of Oxford/Astra } \\
\text { Zeneca }\end{array}$ & 3 & $\begin{array}{l}\text { AZD1222 (ChAdOx1 } \\
\text { nCoV-19) }\end{array}$ & NCT04516746NCT04540393 & {$[103,106]$} \\
\hline & $\begin{array}{l}\text { Janssen Pharmaceutical } \\
\text { Companies } \\
\text { (Johnson\&Johnson) }\end{array}$ & 3 & Ad26.COV2.S & NCT04505722 & {$[103,107]$} \\
\hline & Gamaleya Research Institute & 3 & Gam-COVID-Vac & NCT04530396NCT04564716 & {$[103,106,107]$} \\
\hline & University of Oxford & 1 & ChAdOx1 MERS & NC03399578 & [105] \\
\hline & $\begin{array}{l}\text { ReiThera/ LEUKOCARE/ } \\
\text { Univercells }\end{array}$ & 1 & GRAd-CoV2 & NCT04528641 & {$[105]$} \\
\hline & $\begin{array}{l}\text { Institute of Biotechnology, } \\
\text { Academy of Military } \\
\text { Medical Sciences, PLA of } \\
\text { China }\end{array}$ & 1 & Ad5-nCoV & NCT04552366 & [105] \\
\hline & Vaxart & 1 & VXA-CoV2-1 & NCT04563702 & {$[105]$} \\
\hline & $\begin{array}{l}\text { ImmunityBio, Inc./ } \\
\text { NantKwest Inc. }\end{array}$ & 1 & hAd5 S+N & NCT04591717 & {$[105]$} \\
\hline & $\begin{array}{l}\text { Ludwig-Maximilians-- } \\
\text { University of Munich }\end{array}$ & 1 & MVA-SARS-2-S & NCT04569383 & [105] \\
\hline & City of Hope Medical Center & 1 & $\mathrm{COH} 04 \mathrm{~S} 1$ & NCT04639466 & {$[105]$} \\
\hline \multirow{5}{*}{$\begin{array}{l}\text { REPLICATING } \\
\text { VIRAL } \\
\text { VECTORS }\end{array}$} & Themis Bioscience & 2 & MV-CHIK & NCT02861586 & [105] \\
\hline & $\begin{array}{l}\text { Institut Pasteur/ Themis/ } \\
\text { University of Pittsburgh } \\
\text { CVR/ Merck Sharp \& } \\
\text { Dohme }\end{array}$ & 1 & TMV-083 & NCT04497298 & {$[105]$} \\
\hline & $\begin{array}{l}\text { Beijing Wantai Biological } \\
\text { Pharmacy/ Xiamen } \\
\text { University }\end{array}$ & 1 & $\begin{array}{l}\text { DelNS1- 2019- } \\
\text { nCoVRBD- OPT1 }\end{array}$ & ChiCTR2000037782 & [105] \\
\hline & $\begin{array}{l}\text { Israel Institute for Biological } \\
\text { Research }\end{array}$ & $1 / 2$ & IIBR-100 & NCT04608305 & {$[105]$} \\
\hline & $\begin{array}{l}\text { Merck Sharp \& Dohme/ } \\
\text { IAVI }\end{array}$ & 1 & V590-001 & NCT04569786 & [105] \\
\hline \multirow{10}{*}{$\begin{array}{l}\text { mRNA } \\
\text { VACCINES }\end{array}$} & Curevac & $1 / 2$ & $\mathrm{CVnCoV}$ & NCT04515147 & [103] \\
\hline & CureVac AG & 1 & CV7201 RNActive® & NCT02241135 & [105] \\
\hline & $\begin{array}{l}\text { BioNTech/Fosun } \\
\text { Pharma/Pfizer }\end{array}$ & 3 & $\begin{array}{l}\text { BNT162b2 and } \\
\text { BNT162b1 }\end{array}$ & NCT04368728 & [104-107] \\
\hline & Moderna Therapeutics & 1 & mRNA-1325 & NCT03014089 & [105] \\
\hline & Moderna Therapeutics & 1 & $\begin{array}{l}\text { VAL-506440 } \\
\text { (mRNA-1440) }\end{array}$ & NCT03076385 & [105] \\
\hline & Moderna Therapeutics & 1 & $\begin{array}{l}\text { VAL-339851 } \\
\text { (mRNA-1851) }\end{array}$ & NCT03345043 & {$[105]$} \\
\hline & Moderna Therapeutics & 1 & mRNA-1944 & NCT03829384 & {$[105]$} \\
\hline & Moderna Therapeutics & 1 & $\begin{array}{l}\text { VAL-181388 } \\
\text { (mRNA-1388) } \\
\end{array}$ & NCT03325075 & {$[105]$} \\
\hline & Moderna/NIAID & $1 / 2$ & $\begin{array}{l}\text { LNP-encapsulated } \\
\text { mRNA }\end{array}$ & NCT04283461NCT04405076 & [104] \\
\hline & Moderna/NIAID & 3 & mRNA-1273 & NCT04470427 & {$[103,106,107]$} \\
\hline \multirow[t]{4}{*}{$\begin{array}{l}\text { SaRNA } \\
\text { VACCINES }\end{array}$} & $\begin{array}{l}\text { HDT Biocorp./University of } \\
\text { Washington }\end{array}$ & N/A & $\begin{array}{l}\text { LION/repRNA- } \\
\text { CoV2S }\end{array}$ & $\begin{array}{l}\text { doi: } \\
\text { https://doi.org/10.1126/scitrans } \\
\text { lmed.abc9396 }\end{array}$ & [103] \\
\hline & Imperial College London & 1 & LNP-nCoVsaRNA & ISRCTN17072692 & [103] \\
\hline & Arcturus/Duke-NUS & 2 & ARCT-021 & NCT04480957 & [103] \\
\hline & $\begin{array}{l}\text { People's Liberation Army } \\
\text { (PLA) } \\
\text { Academy of Military } \\
\text { Sciences/ }\end{array}$ & 1 & ARCoV & ChiCTR2000034112 & {$[105]$} \\
\hline
\end{tabular}




\begin{tabular}{|c|c|c|c|c|c|}
\hline GENRE & ESTABLISHMENT & $\begin{array}{l}\text { CLINIC } \\
\text { PHASE }\end{array}$ & $\begin{array}{l}\text { PROPER } \\
\text { NAME }\end{array}$ & $\begin{array}{l}\text { REGISTRY } \\
\text { INDEX }\end{array}$ & REFERENCES \\
\hline & Walvax Biotech. & & & & \\
\hline \multirow{15}{*}{$\begin{array}{l}\text { DNA } \\
\text { VACCINES }\end{array}$} & Genexine Consortium & $1 / 2$ & GX-19 & NCT04445389 & {$[103,107]$} \\
\hline & Cadila Healthcare Limited & $1 / 2$ & nCov Vaccine & CTRI/2020/07/026352 & {$[103]$} \\
\hline & $\begin{array}{l}\text { Osaka } \\
\text { University/AnGes/Takara } \\
\text { Bio }\end{array}$ & $1 / 2$ & $\begin{array}{l}\text { AG0301-COVID19 } \\
\text { and AG0302- } \\
\text { COVID19 }\end{array}$ & NCT04463472NCT04527081 & {$[103]$} \\
\hline & $\begin{array}{l}\text { Inovio } \\
\text { Pharmaceuticals/International } \\
\text { Vaccine Institute }\end{array}$ & $1 / 2$ & INO-4800 & NCT04447781 & [103] \\
\hline & Inovio Pharmaceuticals & 1 & INO-4700 & NCT02670187 & {$[105]$} \\
\hline & Inovio Pharmaceuticals & 1 & $\begin{array}{l}\text { INO-4201 and } \\
\text { INO-4202 }\end{array}$ & NCT02464670 & {$[105]$} \\
\hline & Imperial College London & 1 & GTUß- MultiHIV B & NCT02075983 & [105] \\
\hline & NIAID & 1 & VRC SARS & NCT0009946 & [105] \\
\hline & NIAID & 1 & VRCWNVD & NCT0030417 & [105] \\
\hline & NIAID & 1 & $\begin{array}{l}\text { VRCFLUDNA057- } \\
\text { 00-VP }\end{array}$ & NCT00973895 & [105] \\
\hline & $\begin{array}{l}\text { Osaka University/ AnGes/ } \\
\text { Takara Bio }\end{array}$ & $1 / 2$ & AG0301-COVID19 & NCT04527081 & {$[105]$} \\
\hline & Cadila Healthcare Limited & $1 / 2$ & ZyCoV-D & CTRI/2020/07/026352 & [105] \\
\hline & Genexine Consortium & $1 / 2 \mathrm{a}$ & GX-19 & NCT04445389 & [105] \\
\hline & Symvivo & 1 & bacTLR-Spike & NCT04334980 & {$[105,107]$} \\
\hline & $\begin{array}{l}\text { Providence Health and } \\
\text { Services }\end{array}$ & 1 & CORVax 12 & NCT04627675 & {$[105]$} \\
\hline \multirow{5}{*}{$\begin{array}{l}\text { PROTEIN } \\
\text { SUBUNITS }\end{array}$} & Kentucky Bioprocessing, Inc. & $1 / 2$ & $\begin{array}{l}\text { KBP-COVID-19/ } \\
\text { KBP-201 }\end{array}$ & NCT04473690 & [103] \\
\hline & $\begin{array}{l}\text { FBRI SRC VB VECTOR, } \\
\text { Rospotrebnadsor, Koltsovo }\end{array}$ & $1 / 2$ & EpiVacCorona & NCT04527575 & {$[103]$} \\
\hline & Sanofi Pasteur/GSK & $1 / 2$ & $\begin{array}{l}\text { SARS-CoV-2 vaccine } \\
\text { formulation } \\
1 / 2\end{array}$ & NCT04537208 & [103] \\
\hline & $\begin{array}{l}\text { Anhui Zhigei Longcom } \\
\text { Biopharmaceutical/Institute } \\
\text { of } \\
\text { Microbiology, Chinese } \\
\text { Academy of Sciences }\end{array}$ & 2 & $\begin{array}{l}\text { Recombinant new } \\
\text { coronavirus } \\
\text { vaccine }(\mathrm{CHO} \text { cell })\end{array}$ & NCT04466085 & [103] \\
\hline & Novavax & 3 & $\begin{array}{l}\text { SARS-CoV-2 } \\
\text { rS/Matrix-M1 } \\
\text { Adjuvant (NVX- } \\
\text { CoV2373) }\end{array}$ & $\begin{array}{l}\text { 2020-004123-16 } \\
\text { NCT04533399 }\end{array}$ & [103] \\
\hline
\end{tabular}

\section{Conclusions}

Scientists are working hard to determine the new coronavirus's characterization and develop antivirus therapies and vaccines. However, the virus's pathogenesis is still not fully known, and new studies are needed in this regard. Currently, the only way to prevent the spread of Covid-19 is an effective infection control method. The most appropriate treatment for patients under observation diagnosed with Covid-19 is still unknown. Therefore, treatment protocols should be followed within the framework of existing health rules. As a result, there are three main ways to end pandemics: (i) forming protective antibodies by encountering the disease of the majority of the society, (ii) reducing the disease-prone population by using a vaccine or preventive drugs, and (iii) reducing the infectiousness and pathogenicity (diseasecausing) of the agent. There is no sign of 3rd way regarding the Covid-19 pandemic yet. The 2nd way some vaccines have been developed, and the prophylactic drug has not yet been 
developed, although intensive trials are ongoing for both. There remains only the 1st way. But in that method, too, the death rate is very high. Turkey is one of the countries taking the earliest precautions in the world regarding COVID-19. In this context, Turkey: (i) for the source of the disease (finding the source, reporting the disease, definitive diagnosis, treatment of patients, isolation, search for carriers, surveillance of suspects, health education), (ii) for the infection way (correction of environmental conditions, control of food and beverages, health education, use of personal cleaning and protective equipment, restricting population movements) and (iii) oriented for healthy person safeguards (quarantine, observation) measures have been taken and continue to be taken. Although some vaccines have been developed for the COVID-19 coronavirus, intensive work is still being done to develop specific drugs or vaccines.

\section{Funding}

This research received no external funding.

\section{Acknowledgments}

This research has no acknowledgment.

\section{Conflicts of Interest}

The authors declare no conflict of interest.

\section{References}

1. Cascella, M.; Rajnik, M.; Cuomo, A.; Dulebohn, S.C.; Di Napoli, R. Features, Evaluation and Treatment Coronavirus (COVID-19). StatPearls [Internet], StatPearls Publishing 2021.

2. Jain, N.K.; Tirupathi, R.; Palabindala, V. Coronavirus: Managing a resource crunch and ethical challenges 2020.

3. Lee, C.; Porcine epidemic diarrhea virus: an emerging and re-emerging epizootic swine virus. Virol J 2015, 12, 193, https://doi.org/10.1186/s12985-016-0465-y.

4. Zhu, N.; Zhang, D.; Wang W.; Li X.; Yang B.; Song J. A novel coronavirus from patients with pneumonia in China, 2019. N Engl J Med 2020, 382, 727-733, https://doi.org/10.1056/NEJMoa2001017.

5. Corman, V.M.; Landt, O.; Kaiser, M.; Molenkamp, R.; Meijer, A.; Chu, D.K.W. Detection of 2019 novel coronavirus (2019-nCoV) by real-time RT-PCR. Eurosurveillance 2020, 25, 2000045, https://doi.org/10.2807/1560-7917.ES.2020.25.3.2000045.

6. Mehta, P.; McAuley, D.F.; Brown, M.; Sanchez, E.; Tattersall, R.S.; Manson, J.J. COVID-19: consider cytokine storm syndromes and immunosuppression. Lancet (London, England) 2020, 395, 1033, https://doi.org/10.1016/S0140-6736(20)30628-0.

7. Li, X.; Geng, M.; Peng, Y.; Meng, L.; Lu, S. Molecular immune pathogenesis and diagnosis of COVID-19. J Pharm Anal 2020, 10, 102-108, https://doi.org/10.1016/j.jpha.2020.03.001.

8. Organization WH. Laboratory biosafety guidance related to coronavirus disease 2019 (COVID-19): interim guidance, 12 February 2020. World Health Organization; 2020.

9. Wei, Q.; Wang, Y.; Ma, J.; Han, J.; Jiang, M.; Zhao, L. Description of the First Strain of 2019-nCoV, C-TannCoV Wuhan Strain-National Pathogen Resource Center, China, 2020. China CDC Wkly 2020, 2, 81-82, https://doi.org/10.46234/ccdcw2020.023.

10. Wang, J-W.; Cao, B.; Wang, C. Science in the fight against the novel coronavirus disease 2019 (COVID-19) 2020, 133, 1009-1011, https://doi.org/10.1097/CM9.0000000000000777.

11. Holshue, ML.; DeBolt, C.; Lindquist, S. First Case of 2019 Novel Coronavirus in the United States. N Engl J Med 2020, 382, 929-936, https://doi.org/10.1056/NEJMoa2001191.

12. Organization WH. WHO Director-General's remarks at the media briefing on 2019-nCoV on 11 February 2020. 
13. Lu, H.; Stratton, CW.; Tang, Y. Outbreak of pneumonia of unknown etiology in Wuhan, China: The mystery and the miracle. J Med Virol 2020, 92, 401-402, https://doi.org/10.1002/jmv.25678.

14. Chen, N.; Zhou, M.; Dong, X.; Qu, J.; Gong, F.; Han, Y. Epidemiological and clinical characteristics of 99 cases of 2019 novel coronavirus pneumonia in Wuhan, China: a descriptive study. Lancet 2020, 395, 507513, https://doi.org/10.1016/S0140-736(20)30211-7.

15. Zu, Z.Y.; Jiang, M.D..; Xu, P.P.; Chen, W.; Ni, Q.Q.; Lu, G.M. Coronavirus disease 2019 (COVID-19): a perspective from China. Radiology 2020, 296, E15-E25, https://doi.org/10.1148/radiol.2020200490.

16. Gralinski, L.E.; Menachery, V.D. Return of the Coronavirus: 2019-nCoV. Viruses 2020, 12, 135, https://doi.org/10.3390/v12020135.

17. Zhou, P.; Yang, X.L.; Wang, X.G.; Hu, B.; Zhang, L.; Zhang, W. Discovery of a novel coronavirus associated with the recent pneumonia outbreak in humans and its potential bat origin. BioRxiv. 2020, 10, 914922914952, https://doi.org/10.1101/2020.01.22.914952.

18. Perlman, S. Another decade, another coronavirus. 2020, 382, 760-762, https://doi.org/10.1056/NEJMe2001126.

19. Qiu H-J.; Yuan L-X.; Wu Q-W.; Zhou Y-Q.; Zheng R.; Huang X-K. Using the internet search data to investigate symptom characteristics of COVID-19: a big data study. World J Otorhinolaryngol Neck Surg 2020, 6, S40-S48, https://doi.org/10.1016/j.wjorl.2020.05.003.

20. Sanders, J.M.; Monogue, M.L.; Jodlowski, T.Z.; Cutrell, J.B. Pharmacologic treatments for coronavirus disease 2019 (COVID-19): a review. Jama 2020, 323, 1824-36, https://doi.org/10.1001/jama.2020.6019.

21. Bai, Y.; Yao, L.; Wei, T.; Tian, F.; Jin, D-Y. Presumed asymptomatic carrier transmission of COVID-19. Jama 2020, 323, 1406-7, https://doi.org/10.1001/jama.2020.2565.

22. Zhang, Y.; Odiwuor, N.; Xiong, J.; Sun, L.; Nyaruaba, RO.; Wei, H. Rapid molecular detection of SARSCoV-2 (COVID-19) virus RNA using colorimetric LAMP. MedRxiv 2020, https://doi.org/10.1101/2020.02.26.20028373.

23. Sheikh A.; Al-Taher A.; Al-Nazawi M.; Al-Mubarak AI.; Kandeel M. Analysis of preferred codon usage in the coronavirus $\mathrm{N}$ genes and their implications for genome evolution and vaccine design. J Virol Methods 2020, 277, 113806, https://doi.org/10.1016/j.jviromet.2019.113806.

24. Xu, X.; Chen, P.; Wang, J.; Feng, J.; Zhou, H.; Li, X; Wu, Z.; Pei, H. Evolution of the novel coronavirus from the ongoing Wuhan outbreak and modeling of its spike protein for risk of human transmission. Sience China Life Sciences 2020, 63, 457-460, https://doi.org/10.1007/s11427-020-1637-5.

25. McBride, R.; Van Zyl, M.; Fielding, B.C. The coronavirus nucleocapsid is a multifunctional protein. Viruses 2014, 6, 2991-3018, https://doi.org/10.3390/v6082991.

26. Robson, B. Computers and viral diseases. Preliminary bioinformatics studies on the design of a synthetic vaccine and a preventative peptidomimetic antagonist against the SARS-CoV-2 (2019-nCoV, COVID-19) coronavirus. Comput Biol Med 2020, 119, 103670, https://doi.org/10.1016/j.compbiomed.2020.103670.

27. Wu, A.; Peng, Y.; Huang, B.; Ding, X.; Wang, X.; Niu, P. Genome composition and divergence of the novel coronavirus (2019-nCoV) originating in China. Cell Host Microbe 2020, 27, 325-328, https://doi.org/10.1016/j.chom.2020.02.001.

28. Gao Y.; Yan L.; Huang Y.; Liu F.; Zhao Y.; Cao L. Structure of the RNA-dependent RNA polymerase from COVID-19 virus. Science 2020, 368, 779-782, https://doi.org/10.1126/science.abb7498.

29. Wu, F.; Zhao, S.; Yu, B.; Chen, Y-M.; Wang, W.; Song, Z-G. A new coronavirus associated with human respiratory disease in China. Nature 2020, 579, 265-269, https://doi.org/10.1038/s41586-020-2202-3.

30. Schoeman, D, Fielding, B.C. Coronavirus envelope protein: Current knowledge. Virol J 2019, 16, 1-22, https://doi.org/10.1186/s12985-019-1182-0.

31. Li, X.; Song, Y.; Wong, G.; Cui, J. Bat origin of a new human coronavirus: there and back again. Sci China Life Sci 2020, 63, 461-462, https://doi.org/10.1007/s11427-020-1680-3.

32. Zhou, P.; Yang, X.L.; Wang, X.G.; Hu, B.; Zhang, L.; Zhang, W. A pneumonia outbreak associated with a new coronavirus of probable bat origin. Nature 2020, 579, 270-273, https://doi.org/10.1038/s41586-0202012-7.

33. Schoeman, D.; Fielding, B.C. Coronavirus envelope protein: current knowledge. Virol J 2019, 16, 69, https://doi.org/10.1186/s12985-019-1182-0.

34. Wei, X.; Li, X.; Cui J. Evolutionary perspectives on novel coronaviruses identified in pneumonia cases in China. Natl Sci Rev 2020, 7, 239-242, https://doi.org/10.1093/nsr/nwaa009.

35. Kupferschmidt, K. Genome analyses help track coronavirus' moves 2020, 367, 1176-1177, https://doi.org/10.1126/science.367.6483.1176. 
36. Lake, MA. What we know so far: COVID-19 current clinical knowledge and research. Clin Med (Northfield Il) 2020, 20, 124, https://doi.org/10.7861/clinmed.2019-coron.

37. Bandyopadhyay, S. Coronavirus Disease 2019 (COVID-19): we shall overcome. Clean Technol Environ Policy 2020, 22, 545-546, https://doi.org/10.1007/s10098-020-01843-w.

38. Zhang, Y.; Xiao, M.; Zhang, S.; Xia, P.; Cao, W.; Jiang, W. Coagulopathy and antiphospholipid antibodies in patients with Covid-19. N Engl J Med 2020, 382, e38, https://doi.org/10.1056/NEJMc2007575.

39. Korber, B.; Fischer, W.M.; Gnanakaran, S.; Yoon, H.; Theiler, J.; Abfalterer, W. Tracking changes in SARSCoV-2 Spike: evidence that D614G increases infectivity of the COVID-19 virus. Cell 2020, 182, 812-827, https://doi.org/10.1016/j.cell.2020.06.043.

40. CDC Public Health Image Library (ID 23312: Alissa Eckert, MSMI; Dan Higgins, MAMS), 2020. Available online: https://phil.cdc.gov/details.aspx?pid=23312.

41. Wrapp, D.; Wang, N.; Corbett, K.S.; Goldsmith, J.A.; Hsieh, C-L.; Abiona, O. Cryo-EM structure of the 2019-nCoV spike in the prefusion conformation. Science 2020, 367, 1260-1263, https://doi.org/10.1126/science.abb2507.

42. Commission GO of NH. General Office of National Administration of Traditional Chinese Medicine. Diagnostic and treatment protocol for novel coronavirus pneumonia (Trial version 7). March 4, 2020.

43. Jin, Y.; Yang, H.; Ji, W.; Wu, W.; Chen, S.; Zhang, W. Virology, Epidemiology, Pathogenesis, and Control of COVID-19. Viruses 2020, 12, 372, https://doi.org/10.3390/v12040372.

44. Donoghue, M.; Hsieh, F.; Baronas, E.; Godbout, K.; Gosselin, M.; Stagliano, N. A novel angiotensinconverting enzyme-related carboxypeptidase (ACE2) converts angiotensin I to angiotensin 1-9. Circ Res 2000, 87, 1-9, https://doi.org/10.1161/01.res.87.5.e1.

45. Lu, R.; Zhao, X.; Li, J.; Niu, P.; Yang, B.; Wu, H. Genomic characterisation and epidemiology of 2019 novel coronavirus: implications for virus origins and receptor binding. Lancet 2020, 395, 565-574, https://doi.org/10.1016/S0140-6736(20)30251-8.

46. Yuan M.; Wu NC.; Zhu X.; Lee C-CD.; So RTY.; Lv H. A highly conserved cryptic epitope in the receptorbinding domains of SARS-CoV-2 and SARS-CoV. Science 2020, 368, 630-633, https://doi.org/10.1126/science.abb7269.

47. Yan, R.; Zhang, Y.; Li, Y.; Xia, L.; Zhou, Q. Structure of dimeric full-length human ACE2 in complex with B0AT1. BioRxiv 2020, https://doi.org/10.1101/2020.02.17.951848.

48. Qu, G.; Li, X.; Hu, L.; Jiang, G. An imperative need for research on the role of environmental factors in transmission of novel coronavirus (COVID-19) 2020, 54, 7, 3730-3732, https://doi.org/10.1021/acs.est.0c01102.

49. Velavan, T.P.; Meyer, C.G. The COVID-19 epidemic. Trop Med Int Heal 2020, 25, 278-280, https://doi.org/10.1111/tmi.13383.

50. Wang, C.; Horby, P.W.; Hayden, F.G.; Gao, G.F. A novel coronavirus outbreak of global health concern. Lancet 2020, 395, 470-473, https://doi.org/10.1016/S0140-6736(20)30185-9.

51. Kubina, R.; Dziedzic, A. Molecular and serological tests for COVID-19 a comparative review of SARS-CoV2 coronavirus laboratory and point-of-care diagnostics. Diagnostics 2020, 10, 434-, https://doi.org/10.3390/diagnostics10060434.

52. Liu, W.; Morse, JS.; Lalonde, T.; Xu, S. Learning from the past: possible urgent prevention and treatment options for severe acute respiratory infections caused by 2019-nCoV. Chembiochem 2020, 21, 730-738, https://doi.org/10.1002/cbic.202000047.

53. South, A.M.; Tomlinson, L.; Edmonston, D.; Hiremath, S.; Sparks, M.A. Controversies of renin-angiotensin system inhibition during the COVID-19 pandemic. Nat Rev Nephrol 2020, 16, 305-307, https://doi.org/10.1038/s41581-020-0279-4.

54. Vaduganathan, M.; Vardeny, O.; Michel, T.; McMurray, J.J.V.; Pfeffer, M.A.; Solomon, S.D. Reninangiotensin-aldosterone system inhibitors in patients with Covid-19. N Engl J Med 2020, 382, 1653-1659, https://doi.org/10.1056/NEJMsr2005760.

55. Aronson, J.K.; Ferner, R.E. Drugs and the renin-angiotensin system in Covid-19. BMJ 2020, 369, m1313, https://doi.org/10.1136/bmj.m1313.

56. Cure, E.; Cure, M.C. Angiotensin-converting enzyme inhibitors and angiotensin receptor blockers may be harmful in patients with diabetes during COVID-19 pandemic. Diabetes Metab Syndr Clin Res Rev 2020, 14, 349-350, https://doi.org/10.1016/j.dsx.2020.04.019. 
57. South, A.M.; Shaltout, H.A.; Washburn, L.K.; Hendricks, A.S.; Diz, D.I.; Chappell, M.C. Fetal programming and the angiotensin-(1-7) axis: a review of the experimental and clinical data. Clin Sci 2019, 133, 55-74, https://doi.org/10.1042/CS20171550.

58. Gurwitz, D. Angiotensin receptor blockers as tentative SARS-CoV-2 therapeutics. Drug Dev Res 2020, 81 , 537-540, https://doi.org/10.1002/ddr.21656.

59. Patel, A.B.; Verma, A. COVID-19 and angiotensin-converting enzyme inhibitors and angiotensin receptor blockers: what is the evidence? Jama 2020, 323, 1769-1770, https://doi.org/10.1001/jama.2020.4812.

60. Kuba, K.; Imai, Y.; Rao, S.; Gao, H.; Guo, F.; Guan, B. A crucial role of angiotensin converting enzyme 2 (ACE2) in SARS coronavirus-induced lung injury. Nat Med 2005, 11, 875-879, https://doi.org/10.1038/nm1267.

61. Cao, B.; Wang, Y.; Wen, D.; Liu, W.; Wang, J.; Fan, G. A trial of lopinavir-ritonavir in adults hospitalized with severe Covid-19. N Engl J Med 2020, 382, 1787-1799, https://doi.org/10.1056/NEJMoa2001282.

62. Singh, H.; Kakkar, A.K.; Chauhan, P. Repurposing minocycline for COVID-19 management: mechanisms, opportunities, and challenges. Expert Rev Anti Infect Ther 2020, 18, 997-1003, https://doi.org/10.1080/14787210.2020.1782190.

63. Kim, Y.; Liu, H.; Kankanamalage, A.C.G.; Weerasekara, S.; Hua, D.H.; Groutas, W.C. Reversal of the progression of fatal coronavirus infection in cats by a broad-spectrum coronavirus protease inhibitor. PLoS Pathog 2016, 12, e100553, https://doi.org/10.1371/journal.ppat.1005531.

64. Fauci AS.; Lane HC.; Redfield RR. Covid-19—navigating the uncharted 2020, 382, 1268-1269, https://doi.org/10.1056/NEJMe2002387.

65. Ather, A.; Patel, B.; Ruparel, N.B.; Diogenes, A.; Hargreaves, K.M. Coronavirus disease 19 (COVID-19): implications for clinical dental care. J Endod 2020, 46, 584-595, https://doi.org/10.1016/j.joen.2020.03.008.

66. Cao, X. COVID-19: immunopathology and its implications for therapy. Nat Rev Immunol 2020, 20, 269270, https://doi.org/10.1038/s41577-020-0308-3.

67. Ferner, R.E.; Aronson, J.K. Chloroquine and hydroxychloroquine in Covid-19 2020, 369, m1432, https://doi.org/10.1136/bmj.m1432.

68. COVID-19 Research in Brief_28 March to 3 April, 2020 n.d., https://doi.org/10.1038/d41591-020-00008-y.

69. Wang, W.; Tang, J.; Wei, F. Updated understanding of the outbreak of 2019 novel coronavirus (2019-nCoV) in Wuhan, China. J Med Virol 2020, 92, 441-447, https://doi.org/10.1002/jmv.25689.

70. Dong, L.; Hu, S.; Gao, J. Discovering drugs to treat coronavirus disease 2019 (COVID-19). Drug Discov Ther 2020, 14, 58-60, https://doi.org/10.5582/ddt.2020.01012.

71. Zhou, Y.; Hou, Y.; Shen, J.; Huang, Y.; Martin, W.; Cheng, F. Network-based drug repurposing for novel coronavirus 2019-nCoV/SARS-CoV-2. Cell Discov 2020, 6, 14, https://doi.org/10.1038/s41421-020-0153-3.

72. Tripathy, S.; Dassarma, B.; Roy, S.; Chabalala, H.; Matsabisa, M.G. A review on possible modes of actions of Chloroquine/Hydroxychloroquine: Repurposing against SAR-COV-2 (COVID 19) pandemic. Int J Antimicrob Agents 2020, 56, 106028, https://doi.org/10.1016/j.ijantimicag.2020.106028.

73. Lestari, K.; Sitorus, T.; Instiaty, S.M.; Levita, J. Molecular Docking of Quinine, Chloroquine and Hydroxychloroquine to Angiotensin Converting Enzyme 2 (ACE2) Receptor for Discovering New Potential COVID-19 Antidote. J Adv Pharm Educ Res 2020;10, 1-4.

74. Cortegiani, A.; Ingoglia, G.; Ippolito, M.; Giarratano, A.; Einav, S. A systematic review on the efficacy and safety of chloroquine for the treatment of COVID-19. J Crit Care 2020, 57, 279-283, https://doi.org/10.1016/j.jcrc.2020.03.005.

75. Gao, J.; Tian, Z.; Yang, X. Breakthrough: Chloroquine phosphate has shown apparent efficacy in treatment of COVID-19 associated pneumonia in clinical studies. Biosci Trends 2020, 14, 72-73, https://doi.org/10.5582/bst.2020.01047.

76. Colson, P.; Rolain, J-M.; Lagier, J-C.; Brouqui, P.; Raoult, D. Chloroquine and hydroxychloroquine as available weapons to fight COVID-19. Int $J$ Antimicrob Agents 2020, 55, 105932, https://doi.org/10.1016/j.ijantimicag.2020.105932.

77. Hong-Zhi, DU.; Xiao-Ying, HOU.; Yu-Huan M.; Bi-Sheng, H.; Da-Hui LIU. Traditional Chinese Medicine: an effective treatment for 2019 novel coronavirus pneumonia (NCP). Chin J Nat Med 2020, 18, 206-210, https://doi.org/10.1016/S1875-5364(20)30022-4.

78. Ren, J.; Zhang, A-H.; Wang, X-J. Traditional Chinese medicine for COVID-19 treatment. Pharmacol Res 2020, 155, 104743, https://doi.org/10.1016/j.phrs.2020.104743. 
79. Zhao, J.; Tian, S.S.; Yang, J.; Liu J.; Zhang, W.D. Investigating the mechanism of Qing-Fei-Pai-Du-Tang for the treatment of Novel Coronavirus Pneumonia by network pharmacology. Chin Tradit Herb Drugs 2020, 4 , 829-835.

80. Li, L.C.; Zhang, Z.H.; Zhou, W.C.; Chen, J.; Jin, H.Q.; Fang, H.M.; Chen, Q.; Jin, Y.C.; Qu, J.; Kan, L.D. Lianhua Qingwen prescription for Coronavirus disease 2019 (COVID-19) treatment: Advances and $\begin{array}{llllll}\text { prospects. } \quad \text { Biomedicine } \quad \& \quad \text { Pharmacotherapy } & \mathbf{2 0 2 0}, & 130, & 110641 \text {, }\end{array}$ https://doi.org/10.1016/j.biopha.2020.110641.

81. Yang, Y.; Islam, MS.; Wang, J.; Li, Y.; Chen, X. Traditional Chinese Medicine in the Treatment of Patients Infected with 2019-New Coronavirus (SARS-CoV-2): A Review and Perspective. Int J Biol Sci 2020, 16, 1708-1717, https://doi.org/10.7150/ijbs.45538.

82. Zeng, M.; Li, L.; Wu, Z. Traditional Chinese medicine Lianhua Qingwen treating corona virus disease 2019(COVID-19): Meta-analysis of randomized controlled trials. Plos One 2020, https://doi.org/10.1371/journal.pone.0238828.

83. Ji, S.; Bai, Q.; Wu, X.; Zhang, D-W.; Wang, S.; Shen, J-L. Unique synergistic antiviral effects of Shufeng Jiedu Capsule and oseltamivir in influenza A viral-induced acute exacerbation of chronic obstructive pulmonary disease. Biomed Pharmacother 2020, 121, 109652, https://doi.org/10.1016/j.biopha.2019.109652.

84. Lai, C-C.; Shih, T-P.; Ko, W-C.; Tang, H-J.; Hsueh, P-R. Severe acute respiratory syndrome coronavirus 2 (SARS-CoV-2) and corona virus disease-2019 (COVID-19): the epidemic and the challenges. Int $J$ Antimicrob Agents 2020, 55, 105924, https://doi.org/10.1016/j.ijantimicag.2020.105924.

85. Arabi YM.; Alothman A.; Balkhy HH.; Al-Dawood A.; AlJohani S.; Al Harbi S. Treatment of Middle East Respiratory Syndrome with a combination of lopinavir-ritonavir and interferon- $\beta 1 \mathrm{~b}$ (MIRACLE trial): study protocol for a randomized controlled trial. Trials 2018, 19, 81, https://doi.org/10.1186/s13063-017-2427-0.

86. McKee DL.; Sternberg A.; Stange U.; Laufer S.; Naujokat C. Candidate drugs against SARS-CoV-2 and COVID-19. Pharmacol Res 2020, 157, 104859, https://doi.org/10.1016/j.phrs.2020.104859.

87. Wang, Y.; Fan, G.; Salam, A.; Horby, P.; Hayden, FG.; Chen, C. Comparative effectiveness of combined favipiravir and oseltamivir therapy versus oseltamivir monotherapy in critically ill patients with influenza virus infection. J Infect Dis 2019, 221, 1688-1698, https://doi.org/10.1093/infdis/jiz656.

88. Chow, E.J.; Doyle, J.D.; Uyeki, T.M. Influenza virus-related critical illness: prevention, diagnosis, treatment. Crit Care 2019, 23, 214, https://doi.org/10.1186/s13054-019-2491-9.

89. Sheahan, TP.; Sims, A.C.; Leist, S.R.; Schäfer A.; Won J.; Brown A.J. Comparative therapeutic efficacy of remdesivir and combination lopinavir, ritonavir, and interferon beta against MERS-CoV. Nat Commun 2020, 11, 222, https://doi.org/10.1038/s41467-019-13940-6.

90. Xia, S.; Yan, L.; Xu, W.; Agrawal, A.S.; Algaissi, A.; Tseng C-T.K. A pan-coronavirus fusion inhibitor targeting the HR1 domain of human coronavirus spike. Sci Adv 2019, 5, eaav4580, https://doi.org/10.1126/sciadv.aav4580.

91. Turkish Ministry of Health. https://covid19bilgi.saglik.gov.tr/tr/tedavi (accessed on 2 May 2020).

92. Hu, Z.; Song, C.; Xu, C.; Jin, G.; Chen, Y.; Xu, X. Clinical characteristics of 24 asymptomatic infections with COVID-19 screened among close contacts in Nanjing, China. Sci China Life Sci 2020, 63, 706-711, https://doi.org/10.1007/s11427-020-1661-4.

93. Metintaş, S. Epidemiology of COVID-19. Eurasian Journal of Pulmonology. 2020, 22, 2-7, https://doi.org/10.4103/ejop.ejop_55_20.

94. Duan, K.; Liu, B.; Li, C.; Zhang, H.; Yu, T.; Qu, J. Effectiveness of convalescent plasma therapy in severe COVID-19 patients. Proc Natl Acad Sci 2020, 117, 9490-9496, https://doi.org/10.1073/pnas.2004168117.

95. Satıcı, C.; Kabalak, PA.; Yılmaz, U. Akciğer Kanseri ve COVID-19. Türkiye Solunum Araştırmaları Derneği: TÜSAD, 2020. Available online: https://www.solunum.org.tr.

96. Chen, J.; Liu, D.; Liu, L.; Liu, P.; Xu, Q.; Xia, L.; Ling, Y.; Huang, D.; Song, S.; Zhang, D.; Qian, Z.; Li, T.; Shen Y.; $\mathrm{Lu} \mathrm{H}$. A pilot study of hydroxychloroquine in treatment of patients with common coronavirus disease-19 (COVID-19). J Zhejiang Univ Medical Sci 2020, 49, 215-219, https://doi.org/10.3785/j.issn.10089292.2020.03.03.

97. Juno, J.A.; Tan, H-X.; Lee, WS.; Reynaldi, A.; Kelly, HG.; Wragg, K. Humoral and circulating follicular helper $\mathrm{T}$ cell responses in recovered patients with COVID-19. Nat Med 2020, 26, 1428-1434, https://doi.org/10.1038/s41591-020-0995-0.

98. Zhang L.; Pang R.; Xue X.; Bao J.; Ye S.; Dai Y. Anti-SARS-CoV-2 virus antibody levels in convalescent plasma of six donors who have recovered from COVID-19. Aging (Albany NY) 2020, 12, 6536-6542, https://doi.org/10.18632/aging.103102. 
99. Chen, L.; Xiong, J.; Bao, L.; Shi, Y. Convalescent plasma as a potential therapy for COVID-19. Lancet Infect Dis 2020, 20, 398-400, https://doi.org/10.1016/S1473-3099(20)30141-9.

100.Zhao, J.; Liao, X.; Wang, H.; Wei, L.; Xing, M.; Liu, L. Early virus clearance and delayed antibody response in a case of COVID-19 with a history of co-infection with HIV-1 and HCV. Clin Infect Dis 2020, https://doi.or/10.1093/cid/ciaa408.

101.Wu, F.; Wang, A.; Liu, M.; Wang, Q.; Chen, J.; Xia, S. Neutralizing antibody responses to SARS-CoV-2 in a COVID-19 recovered patient cohort and their implications 2020, https://doi.org/10.1101/2020.03.30.20047365.

102.Covid-19-hastalari-izlem-merkezi-acildi. https://www.istanbul.edu.tr/tr/haber/istanbul-tip-fakultesinde (accessed on 4 May 2020).

103.Izda, V.; Jeffries, M.A.; Sawalha, A.H. COVID-19: A review of therapeutic strategies and vaccine candidates. Clinical Immunology 2021, 1222, 08634, https://doi.org/10.1016/j.clim.2020.108634.

104. Shariarea, M.H.; Parvez, A.K.; Karikasd, G.A.; Kazi, M. The growing complexity of COVID-19 drug and vaccine candidates:challenges and critical transitions. Journal of Infection and Public Health 2021, 14, 214 220, https://doi.org/10.1016/j.jiph.2020.12.009.

105.Pushparajah, D.; Jimenez, S.; Wong, S.; Alattas, H.; Nafissi, N.; Slavcev, RA. Advances in gene-based vaccine platforms to address the COVID-19 pandemic. Advanced Drug Delivery Reviews 2021, 170, 113141, https://doi.org/10.1016/j.addr.2021.01.003.

106.Li, T.; Zhang, T.; Gu, Y.; Li, S.; Xia, N. Current progress and challenges in the design and development of a successful COVID-19 vaccine. Fundamental Research. Available online https://doi.org/10.1016/j.fmre.2021.01.011 (accessed on 26 January 2021).

107.Raja, A.T.A.; Alshamsan, A.; Al-jedai, A. Current COVID-19 vaccine candidates: Implications in the Saudi Population. Saudi Pharmaceutical Journal 2020, 28, 1743-1748, https://doi.org/10.1016/j.jsps.2020.10.019. 